\title{
Impact of Thiocyanate on Catalytic Abilities of Metal Complexes of 4-N-(4-hydroxy-3-((piperidin-1-yl)methyl) phenyl)acetamide (HL). X-ray Crystal Structure of HL
}

\author{
AYOWOLE O. AYENI ${ }^{1,2 *}$, GARETH M. WATKINS ${ }^{1}$, ERIC C. HOSTEN ${ }^{3}$ \\ ${ }^{1}$ Department of Chemistry, Rhodes University, Grahamstown 6140, South Africa \\ ${ }^{2}$ Department of Chemistry, Obafemi Awolowo University, Ile Ife 220005, Nigeria \\ ${ }^{3}$ Department of Chemistry, Nelson Mandela University, Port Elizabeth 6031, South Africa
}

\begin{abstract}
Four new [copper(II) and iron(III)] complexes were synthesized using N-(4-hydroxy-3((piperidin-1-yl)methyl)phenyl)acetamide $(\boldsymbol{H L})$ a Mannich base as ligand. All compounds were successfully characterized by elemental analysis, conductivity measurements, Ultraviolet-visible, Infrared, and Nuclear Magnetic Resonance spectroscopy. Furthermore, the structural determination of $\boldsymbol{H L}$ by X-ray diffraction technique at room temperature showed that the ligand crystallized in the monoclinic crystal system with space group $C c$ and $Z=4$. Structural analysis revealed the chelation of the ligand and the bonding mode of the thiocyanate group. All the metal complexes demonstrated considerable abilities to oxidize 3, 5-di-tert-butylcatechol in DMF under aerobic conditions. Complex 3 (with an iron(III) center) displayed the highest turnover rate of $14.69 \pm 0.71 \mathrm{~h}^{-1}$.
\end{abstract}

Keywords: p-acetamidophenol, copper(II), iron(III), biomimetic, thiocyanate

\section{Introduction}

Mannich reaction offers a convenient route for the amino-methylation of active methylene compounds including phenols, imidazoles, and acetophenones etc. [1-3]. $p$-Acetamidophenol has been employed as a versatile organic starting material in organic synthesis and its use as analgesics, in the formation of azo dyes for textiles, photo electronics and Mannich reaction appears to be most popular [4 -6]. The synthesis of a wide variety of Mannich bases starting with $p$-acetamidophenol has been included in studies carried out by Blade-Font and de Mas Rocabayera [7] as well as Latif et al., [8] also our previous research on the catecholase activity of metal complexes of Mannich bases from $p$ acetamidophenol is available in the literature [9].

The observation that Mannich bases of acetamidophenols generally have not received sufficient attention like those of cresols may be attributed to their tendency to undergo $\mathrm{C}$ - and $\mathrm{N}$ - aminomethylation which may make the synthesis and characterization more cumbersome [10]. A literature survey into metal complexes of $p$-acetamidophenol-Mannich bases as candidates for catecholase activity revealed a lack of research in this regard and served as a motivation to us for further studies. The search for compounds with better biomimetic capabilities has led to our investigation of metal complexes of Mannich bases of this kind as probable candidates for the oxidation of catechol to $o$-benzoquinone.

We report here the synthesis and characterization of [N-(4-hydroxy-3-((piperidin -1-yl)methyl) phenyl)acetamide] along with its metal complexes. The title ligand was first encountered as a precursor in a synthetic route by Sriram et al., [11] but the characterization was not reported, the data has now been expanded by providing its crystal structure as well as results of other spectroscopic characterization. We have also included herein how thiocyanate/isothiocyanate impacts on the catalytic properties of the metal complexes. The spectro-analytical techniques reported include elemental analysis, IR, UV, NMR, and single-crystal X-ray diffraction.

*email: aayeni@oauife.edu.ng 


\section{Materials and methods}

All chemicals were of reagent grade as purchased from Sigma-Aldrich and were used without further purification. Elemental analysis was carried out using Elementar Analysensysteme VarioMICRO V1.62 $\mathrm{GmbH}$ analysis System. NMR spectroscopic analysis was recorded in $\mathrm{CDCl}_{3}$ using $\mathrm{Bruker}$ AMX 300 $\mathrm{MHz}$ spectrometer. Attenuated total reflection Fourier transform infrared (ATR-FTIR) spectra were recorded on a PerkinElmer Spectrum400 spectrophotometer in the range 4000 to $650 \mathrm{~cm}^{-1}$. Electronic spectra were acquired in two solvents (DMF and DMSO) on Perkin Elmer UV/Vis Spectrophotometer - Lamba 25. Molar conductivities of the metal complexes were measured in $10^{-3} \mathrm{M}$ DMSO solution on AZ 86555 conductivity meter. Melting points were determined on Gallenhamp melting point apparatus. For catecholase activity study, metal complexes solutions $\left(10^{-4} \mathrm{M}\right)$ were treated with $10^{-2} \mathrm{M}(100$ equivalents) of 3, 5-di-tertbutyl catechol under aerobic conditions and was followed by kinetic studies.

Step I:Synthesis of 4-N-(4-hydroxy-3-((piperidin-1-yl)methyl)phenyl)acetamide (HL, $\left.\mathrm{C}_{14} \mathrm{H}_{20} \mathrm{~N}_{2} \mathrm{O}_{2}\right)$

The synthesis of the Mannich base (denoted as Ligand or HL) was carried out by adapting the methods previously reported in the literature [12-14]. Equivalent amounts $(3.0 \mathrm{mmol})$ of $p$ acetamidophenol and formaldehyde were taken along with 2.0 equiv. piperidine dissolved in $10 \mathrm{~mL}$ of iso-propanol and heated in a steam bath for $3 \mathrm{~h}$ with the reaction monitored with TLC. Upon the termination of the reaction, the solvent was removed by suction and the remaining mixture taken into ethanol with a little amount of acetone and the mixture was then left overnight in a refrigerator. White crystalline solids suitable for single-crystal X-ray diffraction grew from the mixture. The reaction involved leading to the formation of the ligand is presented in Scheme 1. White crystalline solid, yield $71 \%$, mp: $154^{\circ} \mathrm{C}$, Anal. Cald (\%) for $\mathrm{C}_{14} \mathrm{H}_{20} \mathrm{~N}_{2} \mathrm{O}_{2}, \mathrm{C}, 67.71 ; \mathrm{H}, 8.11 ; \mathrm{N}, 11.28$. Found C, 67.66; H, 8.68; $\mathrm{N}, 11.15 \% .{ }^{1} \mathrm{H}$ NMR $\left(\mathrm{CDCl}_{3}\right): 1.49$ (m, 6H, $\left.\left(-\mathrm{CH}_{2}\right)_{3}\right), 2.12$ (s, 3H: $\left.\underline{\mathrm{C}}_{3} \mathrm{CONH}-\right), 3.05\left(\mathrm{q}, 4 \mathrm{H},\left(-\underline{\mathrm{H}}_{2}\right)_{2} \mathrm{~N}-\right)$, $4.15\left(\mathrm{~s}, 2 \mathrm{H}, \mathrm{ArC}_{2} \mathrm{~N}\right), 6.93-7.66(\mathrm{Ar}-\underline{\mathrm{H}}) ;{ }^{13} \mathrm{C} \mathrm{NMR}\left(\mathrm{CDCl}_{3}\right): 24.35\left(\underline{\mathrm{CH}}_{3} \mathrm{CONH}\right), 24.72$ \& 26.24 $\left.\left(\underline{\mathrm{CH}}_{2}\right)_{3}, 54.30\left(\underline{\mathrm{C}} \bar{H}_{2}\right)_{2} \mathrm{~N}\right), 62.45 \mathrm{Ar}-\underline{\mathrm{CH}}_{2}, 116.46$ - 155.49 (Aromatic carbons), $168.47\left(\mathrm{CH}_{3} \underline{\mathrm{CONH}}\right)$. IR bands (ATR-FTIR, $\left.\mathrm{cm}^{-1}\right): 3276,1253,1149$. Electronic spectra $\left(\mathrm{DMF}, \mathrm{cm}^{-1}\right): 33670 ;\left(\mathrm{DMSO}, \mathrm{cm}^{-1}\right)$ : 38023,33445 .

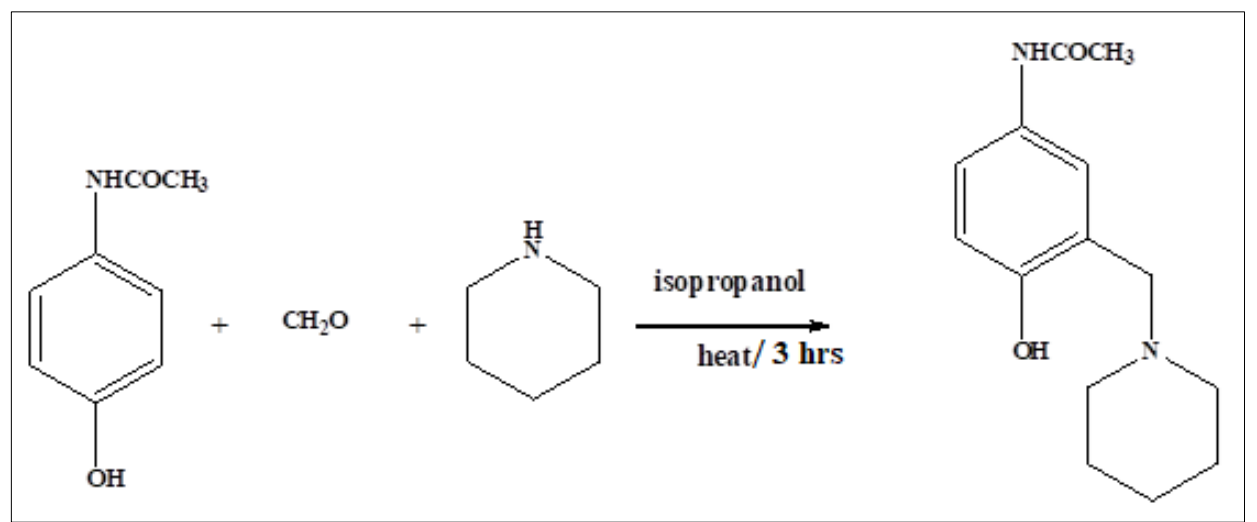

Scheme 1. Synthesis of 4-N-(4-hydroxy-3-((piperidin-1-yl)methyl)phenyl)acetamide (HL)

\section{Step II. Syntheses of $\mathrm{Cu}(\mathrm{II})$ and $\mathrm{Fe}(\mathrm{III})$ complexes}

This was achieved by dissolving the $5 \mathrm{mmol}$ of the Mannich base in chloroform, this was then added to $5 \mathrm{mmol}$ methanolic solutions of Copper (II)/Iron(III) salts and stirred at ambient temperature for $6 \mathrm{~h}$. The preparation of the thiocyanate analogues involved the dissolution of $5 \mathrm{mmol}$ of KSCN in a minimum amount of methanol, plus the solution of the ligand and added to the solution of the metal salt. The obtained precipitate in all cases was then filtered, washed with an equimolar mixture of methanol: chloroform and dried. 
2.3a [CuHLCl 2$] \cdot \mathrm{H}_{2} \mathrm{O} \cdot{ }^{1} /{ }_{4} \mathrm{CHCl}_{3}$ (1): Yield $63 \%$ : mp: $152{ }^{\circ} \mathrm{C}$. Anal. Cald (\%) for $\mathrm{CuC}_{14} \mathrm{H}_{22} \mathrm{~N}_{2} \mathrm{O}_{3}$ $\bullet 1 / 4 \mathrm{CHCl}_{3}$ : C, 39.73; H, 5.20; N, 6.50. Found: C, 39.32, H, 4.96; N, 6.59. $\Lambda_{\mathrm{M}}=29.96 \Omega^{1} . \mathrm{cm}^{2} . \mathrm{mol}^{-1}$. IR bands (ATR-FTIR, $\mathrm{cm}^{-1}$ ): 3339, 1254, $1033 \mathrm{~cm}^{-1}$. Electronic spectra (DMF, $\mathrm{cm}^{-1}$ ): 35842, 32258, 22780 (sh), 11274; (DMSO, cm ${ }^{-1}$ ): 31847, 30395 (sh), 19607, 11628.

$2.3 \mathrm{~b}\left[\mathrm{CuHL}(\mathrm{SCN})\left(\mathrm{H}_{2} \mathrm{O}\right)_{3}\right] \cdot \mathrm{Cl}(2)$ : Yield $54 \%$ : mp: $206^{\circ} \mathrm{C}$. Anal. Cald (\%) for $\mathrm{CuC}_{15} \mathrm{H}_{26} \mathrm{~N}_{3} \mathrm{O}_{5} \mathrm{SCl}$ : C, 39.21; H, 5.37; N, 8.78. Found: C, 39.02, H, 5.37; N, 8.78. $\Lambda_{M}=50.61 \Omega^{1} . \mathrm{cm}^{2} . \mathrm{mol}^{-1}$. IR bands (ATRFTIR, $\left.\mathrm{cm}^{-1}\right): 3337,2106(\mathrm{sp}, \mathrm{s}), 1255,1025,760 \mathrm{~cm}^{-1}$. Electronic spectra (DMF, $\left.\mathrm{cm}^{-1}\right): 37174,30211$, 16103; (DMSO, $\left.\mathrm{cm}^{-1}\right): 34364,12937$.

2.3c $\left[\mathrm{Fe}(\mathrm{HL})_{2} \mathrm{Cl}_{3}\right] \cdot 4 \mathrm{H}_{2} \mathrm{O}(3)$ : Yield $58 \%$ : mp: $169^{\circ} \mathrm{C}$. Anal. Cald (\%) for $\mathrm{FeC}_{28} \mathrm{H}_{36} \mathrm{~N}_{4} \mathrm{O}_{6}: \mathrm{C}, 46.00$; $\mathrm{H}, 6.62 ; \mathrm{N}, 7.66$. Found: $\mathrm{C}, 46.18, \mathrm{H}, 6.88 ; \mathrm{N}, 7.43 . \Lambda_{\mathrm{M}}=59.52 \Omega^{1} . \mathrm{cm}^{2} . \mathrm{mol}^{-1}$. IR bands (ATR-FTIR, $\mathrm{cm}^{-1}$ ): 3364, 1261, $1117 \mathrm{~cm}^{-1}$. Electronic spectra $\left(\mathrm{DMF}, \mathrm{cm}^{-1}\right): 37037,33333,27701$; (DMSO, $\left.\mathrm{cm}^{-1}\right)$ : 32362, 28249, 25316(sh), 19841.

2.3d [FeHL(NCS)Cl $\left.\mathrm{Cl}_{2}\right] \cdot 2 \frac{1}{2} \mathrm{H}_{2} \mathrm{O}$ (4): Yield $46 \%$ : mp: $157{ }^{\circ} \mathrm{C}$. Anal. Cald (\%) for $\mathrm{FeC}_{15} \mathrm{H}_{25} \mathrm{~N}_{3} \mathrm{O}_{4.5} \mathrm{~S}$ : C, 37.67; H, 5.06; N, 8.79. Found: C, 37.34, H, 4.62; N, 8.51. $\Lambda_{\mathrm{M}}=82.54 \Omega^{1} . \mathrm{cm}^{2} . \mathrm{mol}^{-1}$. IR bands (ATRFTIR, $\mathrm{cm}^{-1}$ ): 3276, 2035(s, br), 1257, 1116, $827 \mathrm{~cm}^{-1}$. Electronic spectra (DMF, $\mathrm{cm}^{-1}$ ): 37037, 33445, 27027; (DMSO, $\left.\mathrm{cm}^{-1}\right): 27778,29586$.

\section{Crystallographic study}

"The data was collected using a Bruker KAPPA APEX II single crystal X-ray diffractometer, with a 4-circle Kappa goniometer and sensitive CCD detector. The instrument used a Molybdenum fine focus sealed X-ray tube as an X-ray source and an Oxford Cryostream 700 system for sample temperature control. Bruker's APEX2 software [15] was used for instrument control. The structure was solved using SHELXT-2014 [16] and refined by the least square procedures using SHELXL-2016 [17] with SHELXLE [18] as a graphical interface. Data were recorded for absorption effects using the numerical method implemented in SADABS [15]".

\section{Results and discussions}

\section{Discussion of ligand structure}

Data obtained from ${ }^{1} \mathrm{H}$ NMR spectroscopic study of the Mannich base showed that the aminomethylated group $\left(\mathrm{ArCH}_{2} \mathrm{~N}\right)$ resonated upfield at $4.15 \mathrm{ppm}$ and is indicative of successful aminomethylation at the position ortho to the hydroxyl group of the $p$-acetamidophenol to give a Mannich monobase. This is in close agreement with results from ${ }^{13} \mathrm{C}$ NMR spectroscopy [19]. Table 1 contained crystal data, experimental details as well as a structural refinement for Mannich base (HL).

Table 1. Crystallographic data of $\mathbf{H L}$

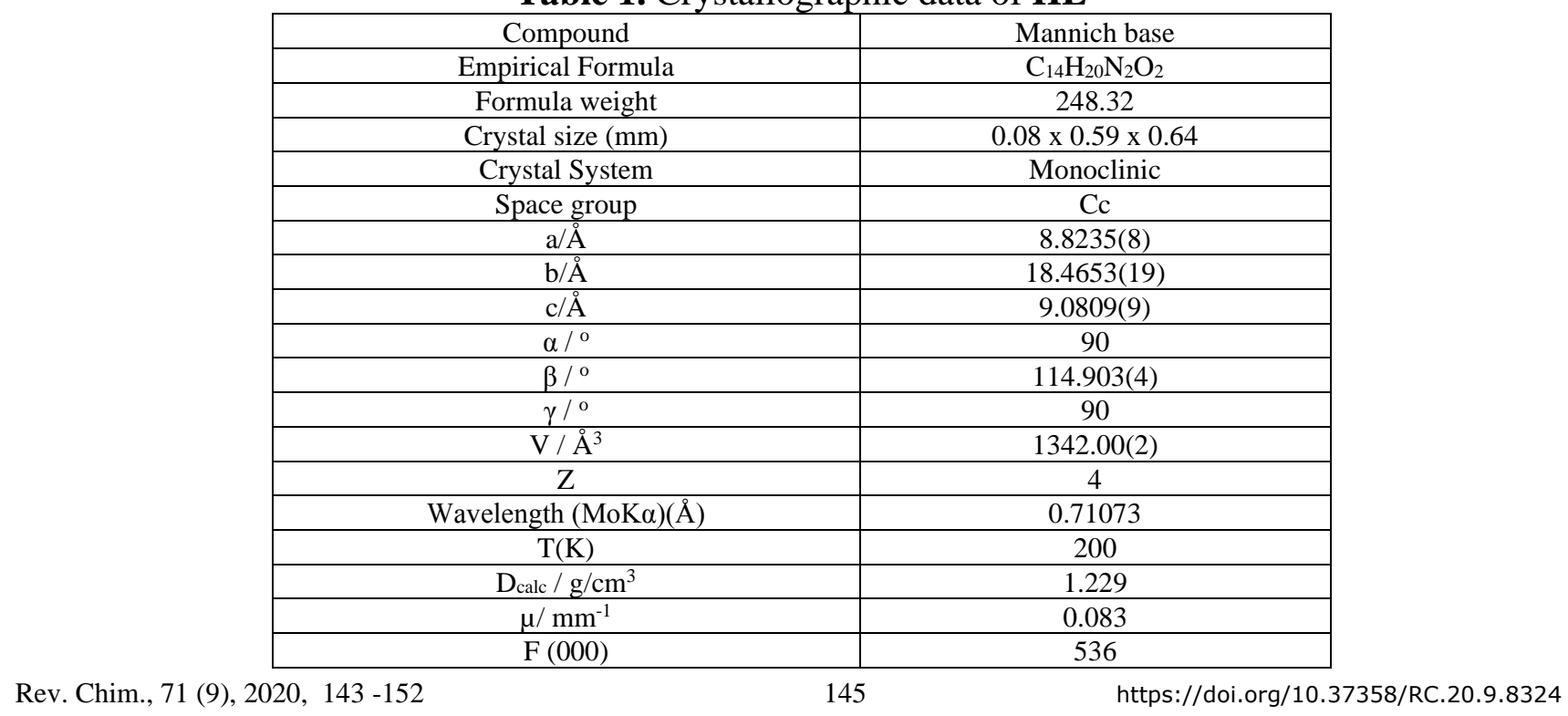




\begin{tabular}{|c|c|}
\hline Refl. Collected/unique & $9221 / 2972$ \\
\hline Data/parameters & $2672 / 168$ \\
\hline$\theta \min /$ max & $2.2 / 28.3$ \\
\hline Final R indices $[\mathrm{I}>2 \sigma(\mathrm{I})]$ & $\mathrm{R} 1=0.0323, \mathrm{wR} 2=0.0821$ \\
\hline GOOF & 1.05 \\
\hline Max/min., $\Delta \rho$ & $0.20 /-0.17$ \\
\hline
\end{tabular}

Table 2. Hydrogen-bond geometry $\left(\AA,{ }^{\circ}\right)$

\begin{tabular}{|c|c|c|c|c|}
\hline$D-\mathrm{H} \cdots A$ & $D-\mathrm{H}$ & $\mathrm{H} \cdots A$ & $D \cdots A$ & $D-\mathrm{H} \cdots A$ \\
\hline $\mathrm{O} 1-\mathrm{H} 1 \ldots \mathrm{N} 1$ & 0.84 & 1.9300 & $2.676(2)$ & 147.00 \\
\hline $\mathrm{N} 2-\mathrm{H} 2 . . \mathrm{O} 2$ & $0.86(2)$ & $2.04(20$ & $2.896(2)$ & $170(2)$ \\
\hline $\mathrm{C} 11-\mathrm{H} 11 \mathrm{~A} . . \mathrm{O} 2$ & 0.99 & 2.5800 & $3.549(3)$ & 165.00 \\
\hline $\mathrm{C} 26-\mathrm{H} 26 . . \mathrm{O} 2$ & 0.95 & 2.4300 & $2.946(3)$ & 114.00 \\
\hline
\end{tabular}

Figures 1 and 2 show the molecular structure of the Mannich base (HL) and its packing arrangements through the a-axis in the unit cells. The crystal structure of (HL) comprised molecules of the Mannich base involved in both intramolecular and intermolecular H-bonding interactions that resulted in the formation of dimers (Table 2).

It was observed that the methyl group of the acetamido shows rotational disorder. Intramolecular $\mathrm{H}-$ bonding interactions occur from the phenyl hydroxyl group to the adjacent piperidylaminomethyl nitrogen $\left[\mathrm{O}-\mathrm{H}---\mathrm{N}, 2.676(2) \AA,<147.00^{\circ}\right]$. The value of the $\mathrm{C}-\mathrm{O}$ bond distance is similar to the literature value of $\mathrm{C}_{\mathrm{ar}} \mathrm{O}$ (1.362 $\AA$ ) [20, 21].
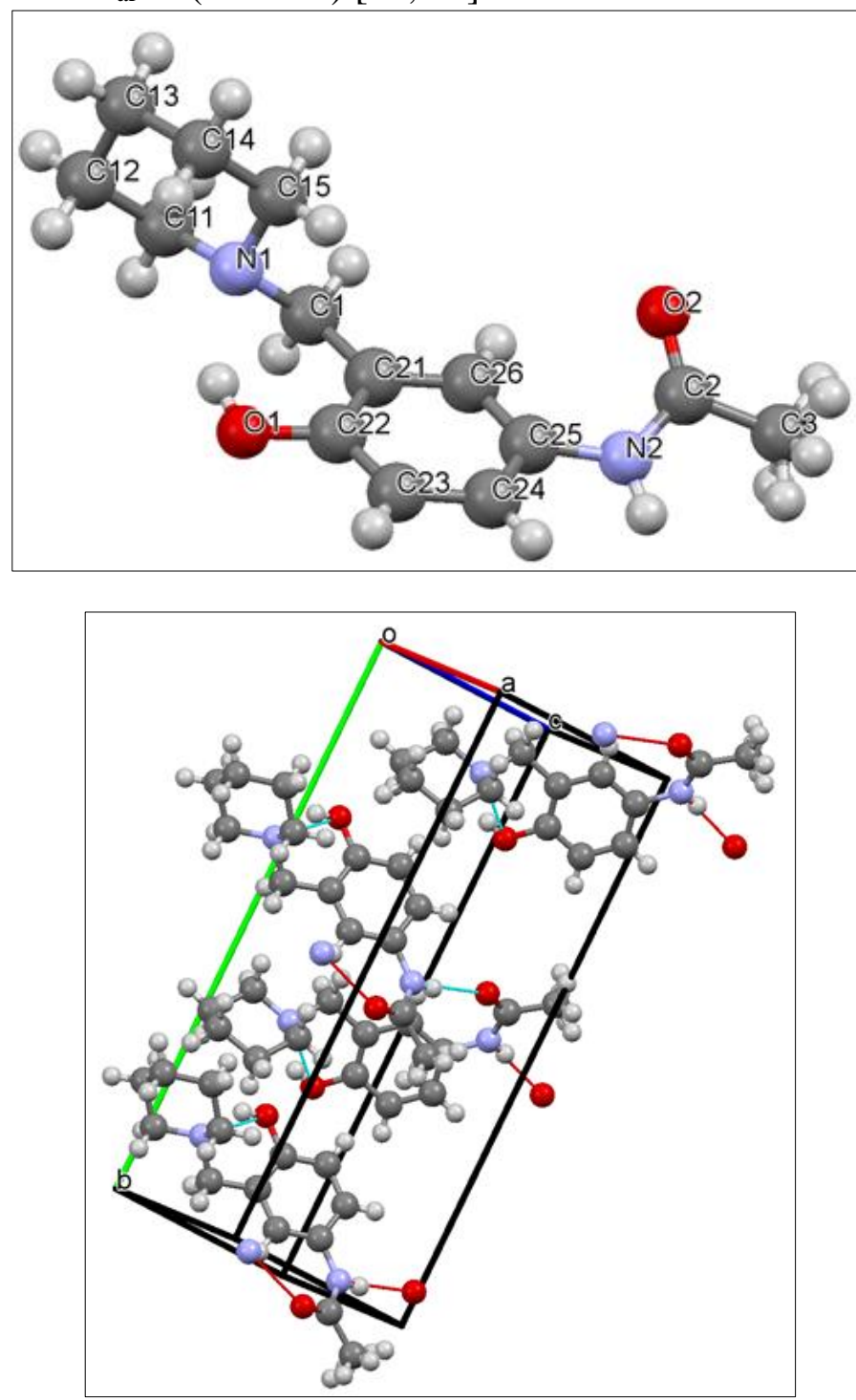

Figure 1. Molecular structure of 4-N-(4-hydroxy-3-((piperidin-1yl)methyl)phenyl)acetamide (HL) with atom labelling. Displacement ellipsoids are drawn at the $50 \%$ probability level
Figure 2. View along $b$ axis of the crystal packing of 4-N-(4-hydroxy-3-((piperidin-1yl)methyl)phenyl)acetamide (HL). H-bonds are represented by dashed lines 


\section{Properties of the complexes}

All the compounds reported herein are brownish in colour, obtained in moderate yields, stable, possess high melting points, all the metal complexes except 3 which is (1:2) are obtained in ratio 1:1 (metal to ligand ratio). Complexes 2, 3 and $\mathbf{4}$ showed higher molar conductivity values in the range $\left(50.61-82.54 \Omega^{1} \cdot \mathrm{cm}^{2} \cdot \mathrm{mol}^{-1}\right)$ than $\mathbf{1}$ and the ligand indicating that they are (1:1) electrolytes [22, 23].

\section{InfraRed Spectroscopy}

Figure 3 contains the IR spectra of $\mathbf{H L}$ as well as its metal complexes. The hydroxyl group of $\mathbf{H L}$ resonated as a sharp band at $3276 \mathrm{~cm}^{-1}$ (presence of Hydrogen bonding as observed in solution by NMR) but increased to within the range of $3276-3364 \mathrm{~cm}^{-1}$ and became broader. This suggested coordination with the loss of hydrogen bonding and possibly the presence of coordinated water molecules particularly in the iron(III) complexes. Further upward shifts observed in the $v \mathrm{C}-\mathrm{O}$ of $\mathbf{H L}$ at $1253 \mathrm{~cm}^{-1}$ to within 1254-1261 $\mathrm{cm}^{-1}$ supported the bonding of the phenolic hydroxyl group to the metal center. Upward shifts in $v \mathrm{C}-\mathrm{O}$ are usually observed in the case of a deprotonated hydroxyl group leading to the formation of a direct metal-oxygen bond. An increase in the $\mathrm{vC}-\mathrm{O}$ without deprotonation has been reported by Mahmoud and El-Haty [24].

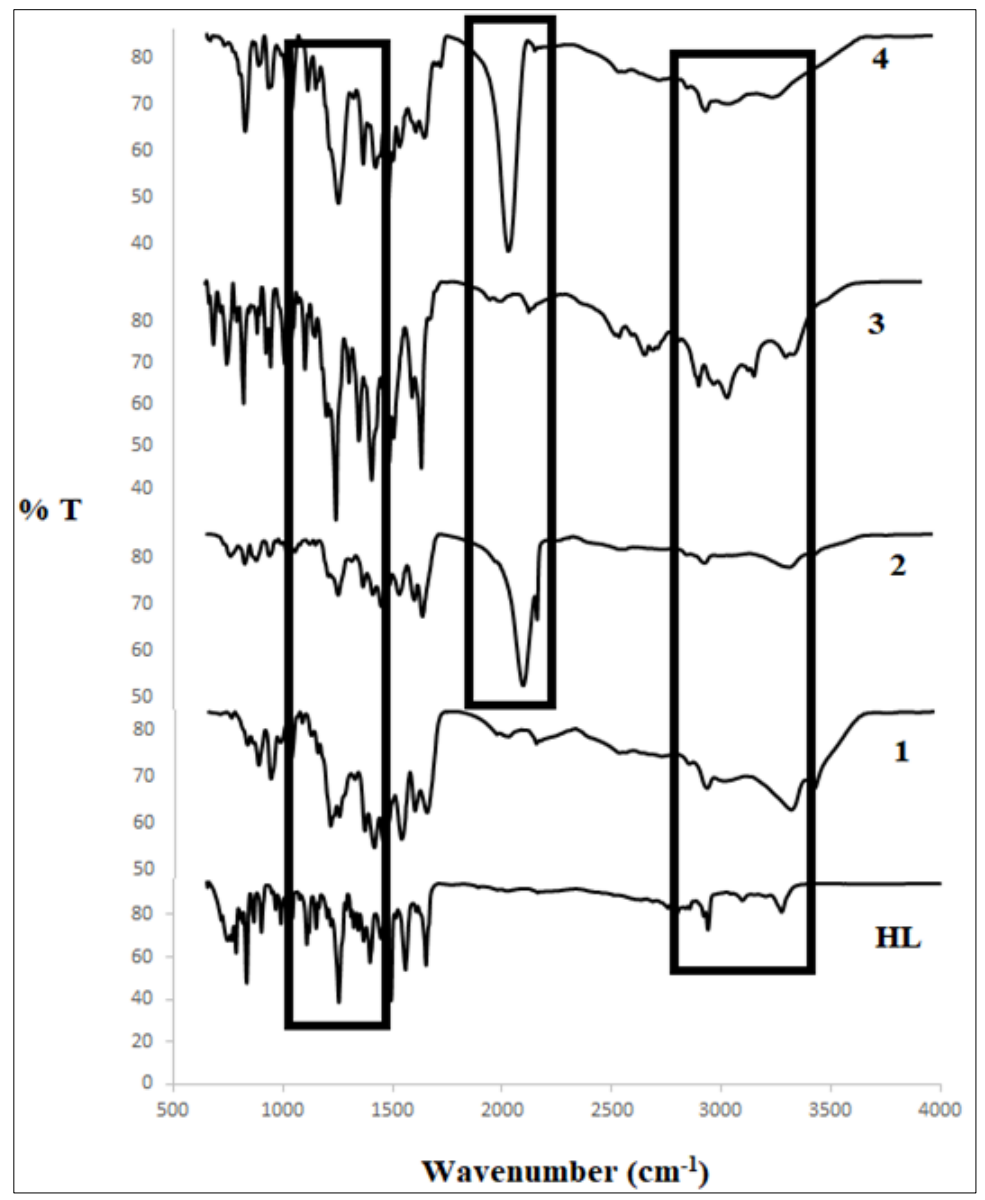

Figure 3. FT-IR spectra of HL and its metal complexes. Important bands of the spectra are highlighted

Evidence to support the involvement of the amine nitrogen atom is the lowering by $\sim 22-124 \mathrm{~cm}^{-1}$ the stretching frequency of the bond $(\mathrm{C}-\mathrm{N})$ in the Mannich base at $1149 \mathrm{~cm}^{-1}$. This led to the appearance of broad bands for $v \mathrm{C}-\mathrm{N}$ in all the metal complexes and most noticeable in the case of 2; this further suggests bonding of the $\mathrm{N}$-atom to the central metal $[25,26]$. Complex $\mathbf{3}$ seemed to be a big beneficiary of complexation owing to the strengthening of its $v \mathrm{C}-\mathrm{O}$ and least reduction in the $\mathrm{vC}-\mathrm{N}$. 
The successful inclusion of thiocyanate within the metal complexes was confirmed from the infrared spectra by the observation of absorption bands at $2106 \mathrm{~cm}^{-1}$ and $2035 \mathrm{~cm}^{-1}$ in the copper(II) (2) and iron complex(III) (4) respectively. It can therefore be inferred that $\mathbf{2}$ contained thiocyanato while $\mathbf{4}$ contained isothiocyanato. This was further supported by the presence of the band due to $\mathrm{VCS}$ at 760 and $827 \mathrm{~cm}^{-1}$ in 2 and 4 [27, 28].

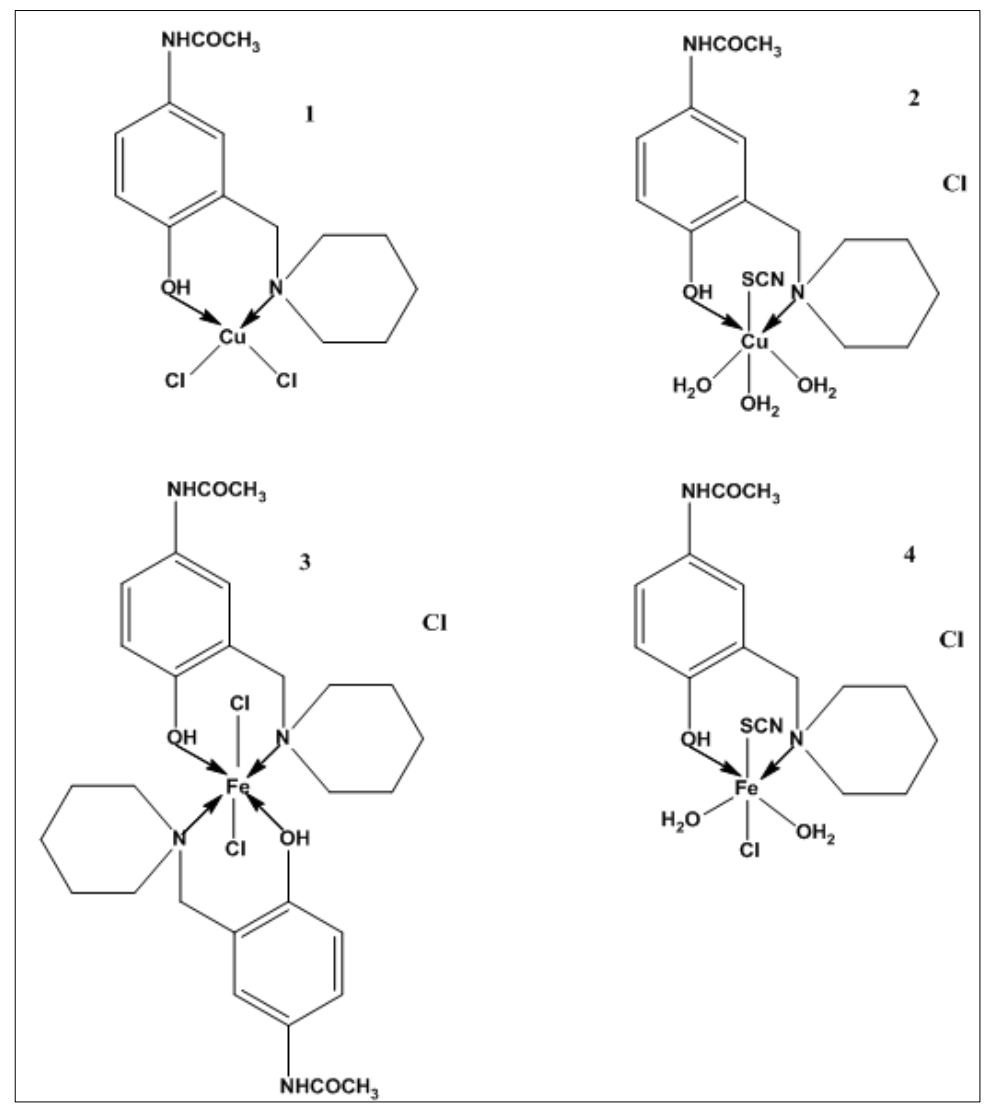

Figure 4. Proposed structures of complexes $1-4$

\section{UV-Vis Spectroscopy}

In 1, the absorption band at $22780 \mathrm{~cm}^{-1}$ (sh) observed in DMF and $19608 \mathrm{~cm}^{-1}$ in DMSO was adjudged to be an "LMCT" and the d-d transition is recorded at $11274 \mathrm{~cm}^{-1}$ typical of an octahedral geometry while in DMSO the transition at $11628 \mathrm{~cm}^{-1}$ was assigned to ${ }^{2} \mathrm{E}_{\mathrm{g}} \rightarrow{ }^{2} \mathrm{~T}_{2 \mathrm{~g}}$ transition in an octahedral geometry. In 2, single transitions in DMF at $16103 \mathrm{~cm}^{-1}$ and $12937 \mathrm{~cm}^{-1}$ in DMSO were assigned to ${ }^{2} \mathrm{E}_{\mathrm{g}} \rightarrow{ }^{2} \mathrm{~T}_{2 \mathrm{~g}}(\mathrm{~d}-\mathrm{d})$ transitions commonly observed in octahedral geometries of $\mathrm{Cu}$ (II) complexes of Mannich bases [29, 30].

The data generally obtained from the UV-Vis spectra of Iron(III) complexes are known not to be reliable in making full diagnostic conclusions. The band $\left(29586-25316 \mathrm{~cm}^{-1}\right)$ was assigned to the charge-transfer transition of the phenolate oxygen to the singly occupied $e_{\mathrm{g}}$ orbitals of iron(III), the band at $19841 \mathrm{~cm}^{-1}$ is also a CT transition [31, 32].

The band at $30303-25000 \mathrm{~cm}^{-1}$ was assigned to "phenolato to copper(II) charge transfer" as reported in the literature. Also, in studies conducted by Thirumavalavan et al., on iron(III) phenolate complexes, phenolate - CT transition was observed at $20408-18181 \mathrm{~cm}^{-1}$ [33]. Proposed structures of metal complexes are depicted in Figure 4.

\section{Evaluation of Catecholase Activities}

Many recent examinations of catecholase activity of coordination compounds utilized 3, 5-ditertbutylcatechol $(3,5$-DTBC) as the model substrate because it has low redox potential that makes it 
easy to oxidize and the presence of bulky $t$-butyl substituents discourages over-oxidation reactions such as ring-opening [34].

3, 5-di-tert-butylquinone (3,5-DTBQ); the oxidation product is very stable and displays absorption maximum ca $399 \mathrm{~nm}$ in DMF. The preliminary investigation was carried out by treating $10^{-4} \mathrm{M}$ DMF solutions of metal complexes with 100 equivalents of 3,5-DTBC in the presence of oxygen. After the addition of the catecholic substrate, a band $c a 399 \mathrm{~nm}$ was identified in the UV-Vis scan at $5 \mathrm{~min}$ interval, thus indicating the formation of 3,5-DTBQ. An example is given of complex 2 below in Figure 5 .

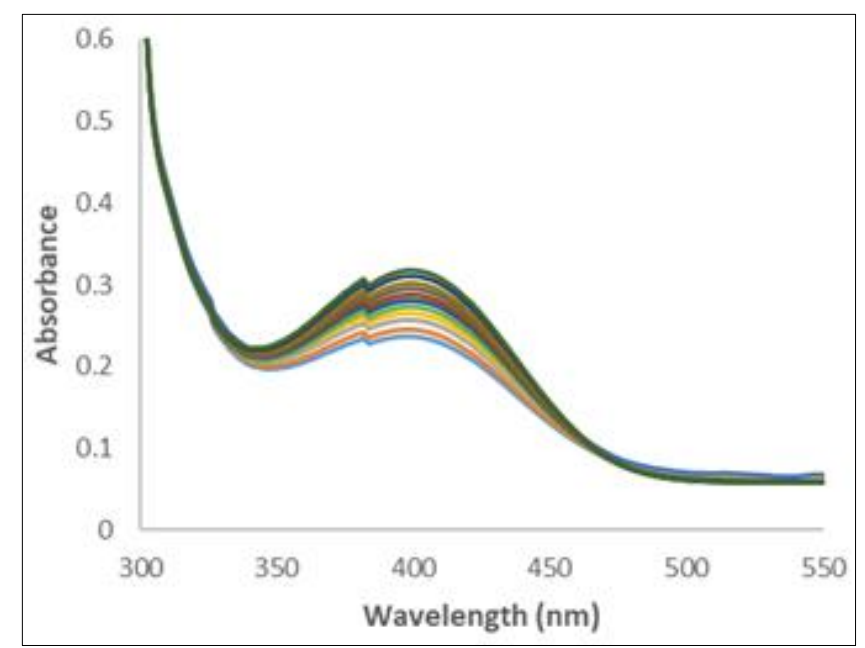

Figure 5. Increase in absorbance at $\sim 399 \mathrm{~nm}$, after the addition of 100 equivalents of 3,5-DTBC to a $10^{-4} \mathrm{M}$ DMF solution of 2.

[Spectra were recorded at an interval of $5 \mathrm{~min}$ for $1 \mathrm{~h}$ ]

Detailed kinetic studies of the oxidation process using each of the metal complexes were carried out by the method of initial rates at $399 \mathrm{~nm}$ [35 - 37]. The rate constant for the process was determined from the plot of $\log [\mathrm{A} \alpha /(\mathrm{A} \alpha-\mathrm{At})]$ against time as shown in Figure 6.

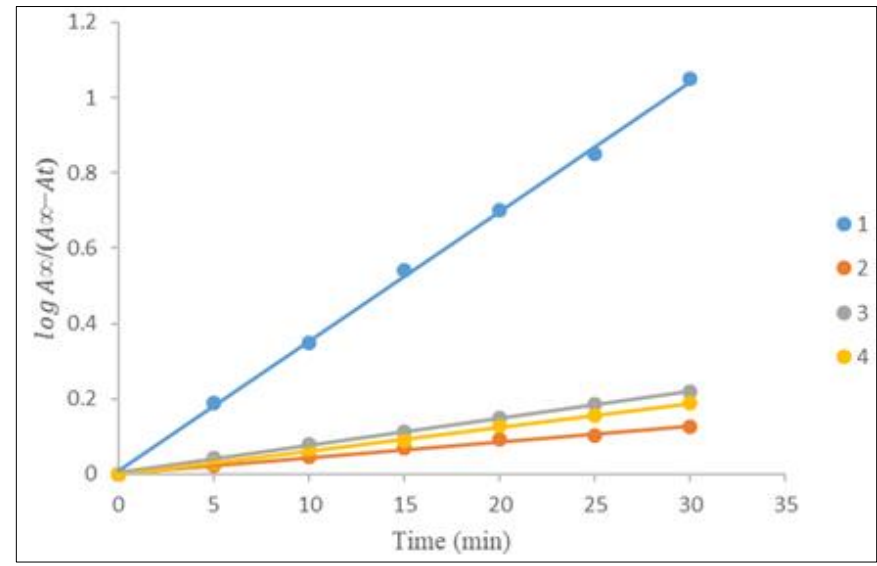

Figure 6. Catecholase activity of the metal complexes.

The figure shows the course of absorption maxima at $399 \mathrm{~nm}$ with time for 100 equivalents of 3,5-DTBC in solutions of $10^{-4} \mathrm{M}$ complexes $\mathbf{1}$ - 4 in DMF

The reliance of the oxidative process on substrate concentration was studied by using $10^{-4} \mathrm{M}$ solutions of 1, 2, 3 and $\mathbf{4}$ and varying the amounts of 3, 5-DTBC from 20 to 100 equivalents. At minimum substrate presence first-order dependence was observed while at higher substrate concentrations, saturation kinetics took place. The dependence on substrate concentration suggested that the first step of the catalytic cycle involved the binding of the substrate to the catalyst. 


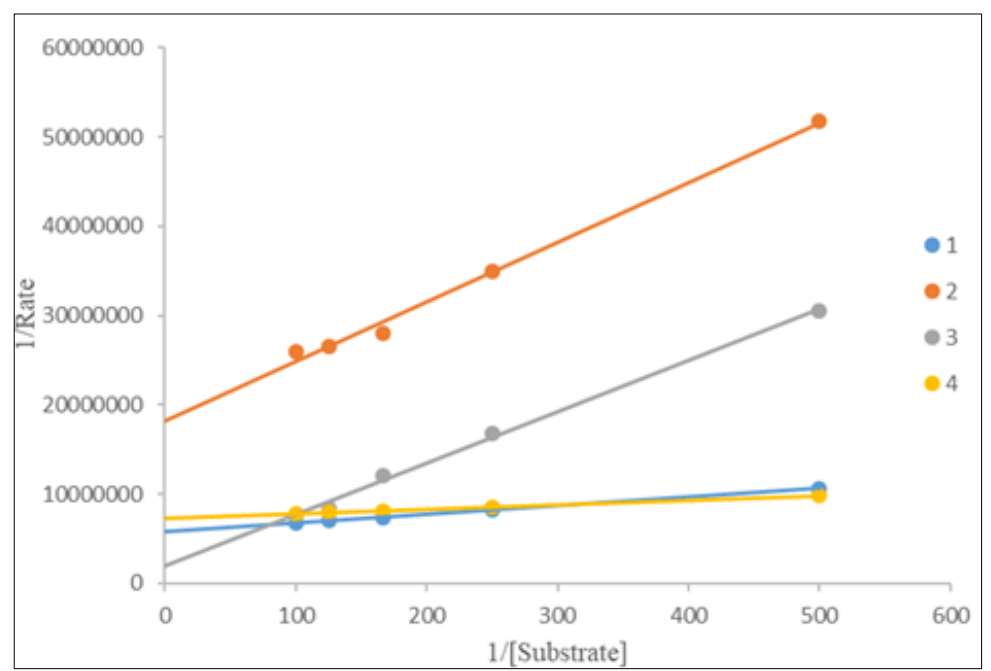

Figure 7. The Lineweaver-Burk plot for the metal complexes 1- 4

The data obtained were analyzed by Michaelis-Menten kinetics while the Michaelis- Menten constant $\left(\mathrm{K}_{\mathrm{M}}\right)$ and maximum initial rate $\left(\mathrm{V}_{\max }\right)$ were determined by linearization using Lineweaver-Burk plots depicted in Figure 7 . The turnover number $\left(\mathrm{k}_{\text {cat }}\right)$ values were calculated by dividing the $\mathrm{V}_{\max }$ values by the concentration of the corresponding complexes [38 - 40]. Detailed results are presented in Table 3.

Table 3. Kinetics parameters for the oxidation of the substrate catalyzed by the metal complexes $\mathbf{1}-\mathbf{4}$

\begin{tabular}{cccc}
\hline Compound & $\mathrm{V}_{\max }\left(\mathrm{Ms}^{-1}\right)$ & $\mathrm{K}_{\mathrm{M}}(\mathrm{M})$ & $k_{\mathrm{cat}}\left(\mathrm{h}^{-1}\right)$ \\
\hline 1 & $(1.72 \pm 0.09) \times 10^{-7}$ & $(1.67 \pm 0.08) \times 10^{-3}$ & $6.19 \pm 0.30$ \\
2 & $(5.18 \pm 0.30) \times 10^{-8}$ & $(3.46 \pm 0.15) \times 10^{-3}$ & $1.86 \pm 0.09$ \\
3 & $(4.08 \pm 0.21) \times 10^{-7}$ & $(2.35 \pm 0.12) \times 10^{-2}$ & $14.69 \pm 0.71$ \\
4 & $(1.38 \pm 0.06) \times 10^{-7}$ & $(7.12 \pm 0.40) \times 10^{-4}$ & $4.96 \pm 0.22$ \\
\hline
\end{tabular}

The order of catecholase activity is: $\mathbf{3}>\mathbf{1}>\mathbf{4}>\mathbf{2}$. Complex $\mathbf{3}$ is most stable because of chelate effect as well as possessing a metal center richly supplied with electrons and that is proposed to enhance its catalytic properties. Several factors have been reported to affect catecholase activity, chiefly among them are the presence of thiocyanate and the nature of coordination of the metal center [41 - 43]. The reason for the better catalytic properties of the $\mathrm{Fe}(\mathrm{III})$ complexes over the $\mathrm{Cu}$ (II) complexes may be attributed to sthe higher reduction potential of their metal center which is a vital process in the catalytic process. Comparable or higher values of $k_{\text {cat }}$ have also been observed in some previous studies with the nature of the solvent playing a great role $[44,45]$. It is believed that a less coordinating solvent than DMF may result in higher turnover rates because of a more favourable formation of the metal-substrate adduct.

\section{Conclusions}

In this study, the synthesis and characterization of a Mannich base, 4-N-(4-hydroxy-3-((piperidin-1yl)methyl)phenyl) acetamide (HL) and its $\mathrm{Cu}$ (II) and $\mathrm{Fe}(\mathrm{III})$ complexes by spectro-analytical techniques have been reported. Also, the crystal structure of $\mathbf{H L}$ was determined by X-ray diffraction at room temperature. According to the analytical and spectral data, HL behaved as a bidentate ligand in the coordination process. The inclusion of the thiocyanate in the metal coordination sphere was verified by Infrared Spectroscopy with the observation of bands in the range $2035-2110 \mathrm{~cm}^{-1}$. Also, it was further observed that the thiocyanate group had an unfavourable impact on the catalytic abilities of the metal complexes. 


\section{Supplementary material}

Crystallographic data for the structural analysis have been deposited at the Cambridge Crystallographic Data Centre, CCDC No. 1556952. Copies of this information may be obtained free of charge from the Director, CCDC, 12 Union Road, Cambridge CB2 1EZ, UK (fax: +44-1223-336033; e-mail: deposit@ccdc.cam.ac.uk or www:http://www.ccdc.cam.ac.uk).

Acknowledgments: The authors wish to particularly acknowledge Rhodes University, South Africa for research support.

\section{References}

1.DE KONING MC, HORN G, WOREK F, VAN GROL M. E. J. Med. Chem. 157, 2018, p. 151

2.AYENI AO, WATKINS GM, HOSTEN EC. J. Struct. Chem. 59, 2018, p. 1746

3.ORIO M, PHILOUZE C, JARJAYES O, NEESE F, THOMAS F. Inorg. Chem. 49, 2010, p. 646

4.PINTAL M, KRYCZKA B, MARSURA A, PORWANSKI S. Carbohy. Res. 386, 2014, p. 18

5.KOH J, GREAVES AJ. Dyes \& Pigments (SCI) 50, 2001, p. 117

6.AYENI AO, WATKINS GM. Turk. J. Chem. 42, 2018, p. 1275

7.BLADE-FONT A, de MAS ROCABATERA T. J. Chem. Soc. Perkin Transactions 1982; 841

8.LATIF T, JAVED T, LYNCH DE, PRYCE RJ, BYRIEL KA. Aust. J. Chem. 52, 1999, p. 909

9.AYENI AO, WATKINS GM. Monatshefte für Chemie - Chemical Monthly 149, 2018, p. 2175

10.ROMAN G., Rev. Chim., 63(3), 2012, p. 255

11.SRIRAM D, DEVAKARAM RV, DINAKARAN M, YOGEESWARI P. Med. Chem. Res. 19, 2010, p. 524.

12.WEN-HSIN H, HSIAO-FENG L, AN-RONG L. Chi. Pharm. J. (Taipei, Taiwan), 54, 2002, p. 485. 13.ANDREA P, GIANMARIO C. Boll. Chim. Farma 105, 1966, p. 503

14.BUYUKKIDAN N, BUYUKKIDAN B, BULBUL M, ÖZER S, GONCA YALCIN H. J. Enzy. Inh. Med. Chem. 28, 2013, p. 337.

15.APEX2, SADABS and SAINT, Bruker AXS Inc., Madison, Wisconsin, USA, (2010)

16.SHELDRICK GM. Acta Crystallographica A71, 2015a, p. 3

17.SHELDRICK GM. Acta Crystallographica C71, 2015, p. 3

18.HUBSCHLE CB, SHELDRICK GM, DITTRICH B, J. Appl. Cryst. 44, 2011, p.1281.

19.BRYCKI B, MACIEJEWSKA H, BRZEZINSKI B, ZUNDEL G. J. Mol. Struct. 246, 1991, p. 61. 20.ALLEN FH, KENNARD O, WATSON DG, BRAMMER L, ORPEN AG. J. Chem. Soc. Perkin Transactions. II 1987; p.194.

21.AYENI AO, WATKINS GM, Hosten EC. Bull. Chem. Soc. Eth. 33, 2019, p. 341

22.SEARS PG, LESTER GR, DAWSON LR. J. Phys. Chem. 60, 1956, p. 1433.

23.ALI I, WANI WA, SALEEM K. Syn. React. Inorg Met-Org. Nano-Met. Chem. 43, 2013, p. 1162

24.MAHMOUD MR, El-HATY MT. J. Inorg. Nuc. Chem. 42, 1980, p. 349.

25.HARBATSEVICH HI, LOGINOVA NV, KOVALCHUK TV, OSIPOVICH NP, GRES AT. J. Appl. Spec. 82, 2015, p. 713

26.SHARMA M, SALEEM M, PATHANIA MS, SHEIKH HN, KALSOTRA B.L. Chi. J. Chem. 27, 2009 , p. 311.

27.KABESOVA M, GAZO J. Chemické Zvesti 34, 1980, p. 800

28.USHA RJ, SUGANTHI ARB, JOSEPH V, SAGAYARAJ P. Spec. Lett. 48, 2015, p. 74

29.AL-JEBOORI MJ, ABDUL-GHANI AJ, AL-KARAWI AJ. Trans. Met. Chem. 33, 2008, p. 925

30.BHARATHI KS, SREEDARAN S, PRIYA PH, RAHIMAN AK, RAJESH K. J. Coord. Chem. 62, 2009, p. 1356

31.MERKEL M, MULLER FK, KREBS B. Inorg. Chim. Acta 337, 2002, p. 308

32.DAVIS MI, ORVILLE AM, NEESE F, ZALESKI JM, LIPSCOMB JD. J. Am. Chem. Soc. 124, 2002, p. 602 
33.THIRUMAVALAVAN M, AKILAN P. KANDASWAMY M, CHINNAKALI K, KUMAR GS. Inorg. Chem. 42, 2003, p. 3308

34.MUKHERJEE J, MUKHERJEE R. Inorg. Chim. Acta 337, 2002, p. 429

35.VIJAYAN P, VIJAYAPRITHA S, RUBA C, VISWANATHAMURTHI P, LINERT W. Monatshefte für Chemie - Chemical Monthly 150, 2019, p. 1059

36.BANU KS, CHATTOPADHYAY T, BANERJEE A, MUKHERJEE M, BHATTACHARYA K. Dalton Trans. 2009, p. 8755

37.BHARDWAJ VK, VK, ALIAGA-ALCALDE N, CORBELLA M, HUNDAL G. Inorg. Chim. Acta 363, 2010, p. 97

38.BISWAS A, DAS KL, DREW MGB, AROMI G, GAMEZ P. Inorg. Chem. 51, 2012, p. 7993

39.KOVAL IA, BELLE C, SELMECZI K, PHILOUZE C, SAINT-AMAN E. J. Biol. Inorg. Chem. 10, 2005, p. 739

40.NEVES A, ROSSI LM, BORTOLUZZI AJ, MANGRICH AS, HAASE W. J. Braz. Chem. Soc. 12, 2001, p. 747

41.MITRA M, MAJI AK, GHOSH BK, RAGHAVAIAH P, RIBAS J. Polyhedron 67, 2014, p. 19

42.CHAKRABORTY P, MAJUMBER I, KARA H, CHATTPPADHYAY SK, ZANGRANDO E. Inorg. Chim. Acta 436, 2015, p. 139

43.RAMADAN AM, SHABAN SY, IBRAHIM MM. J. Coord. Chem. 64, 2011, p. 3376

44.ADAK P, DAS C, GHOSH B, MONDAL S, PAKHIRA B. Polyhedron 119, 2016, p. 39.

45.DASGUPTA S, MANDAL A, SAMANTA D, ZANGRADO E, MAITY S, DAS D. Inorg. Chim. Acta 505, 2020, p. 119480

Manuscript received: 13.02 .2020 